\title{
AUtONOMY IN THE TRANSITION FROM FOREIGN LANGUAGE LEARNING TO FOREIGN LANGUAGE TEACHING
}

\author{
(Autonomia na transição da aprendizagem de língua estrangeira \\ para o ensino de língua estrangeira)
}

\author{
Phil Benson \\ (Hong Kong Institute of Education) \\ Jing HuANG
}

(Zhanjiang Teachers University / University of Hong Kong)

\begin{abstract}
This paper discusses the historical development of the concept of teacher autonomy in foreign language education and its relationship to the idea of learner autonomy. Three major phases in the development of conceptions of teacher autonomy are reviewed, involving attention to teacher roles in autonomous learning projects, professional development and professional freedom. Different ways of conceptualising the link between teacher and learner autonomy are discussed and an alternative conception based on the notion of transition from learner autonomy to teacher autonomy in learning-teaching careers is proposed.
\end{abstract}

KEY-WORDS: Learner autonomy; Teacher autonomy; Self-directed learning; Teacher development.

RESUMO: Este trabalho discute o desenvolvimento histórico do conceito de autonomia do professor de língua estrangeira e suas relações com a idéia de autonomia do aprendiz. São analisadas três fases importantes do desenvolvimento dos conceitos de autonomia do professor, envolvendo a atenção aos papéis do professor em projetos voltados para o desenvolvimento da autonomia na aprendizagem, o desenvolvimento profissional e a liberdade profissional. São discutidas diferentes formas de se conceituar o relacionamento entre a autonomia do professor e do aluno e é proposta uma perspectiva alternativa, baseada na noção de transição da autonomia do aprendiz para a autonomia do professor no processo de ensino-aprendizagem.

PALAVRAs-CHAVE: Autonomia do aprendiz; autonomia do professor; aprendizagem autodirecionada; desenvolvimento do professor. 


\section{Introduction}

Over the past twenty years or so, the concept of autonomy, together with related concepts such as independent learning, self-direction and selfregulation, has become increasingly important in the educational literature, where it has been viewed as both a desirable goal of education and a constituent element of good teaching and learning (Areglado 1996; Boud 1988; Brockett \& Hiemstra 1991; Candy 1991; Hammond \& Collins 1991; Schunk \& Zimmerman 1994; 1998; Zimmerman \& Schunk 1989). The idea of autonomy has also acquired a particular importance in the field of foreign language education, in which more than 20 book-length publications have been published since the turn of the century (Benson 2007).

After 30 years or so of research and practice, there is now a fair degree of consensus on what learner autonomy means in the context of language education. Over the past decade, however, the notion of teacher autonomy has also come to the fore and to date there is much less consensus over its meaning and significance. One reason for this is that there has been far less discussion of teacher autonomy beyond the field of foreign language education. The teacher education literature has tended to equate teacher autonomy with professional freedom, or the degree to which curricula and institutions allow scope for teacher discretion. It is in this sense, for example, that Anderson (1987) used the term, arguing that the rise of uniform staff development programmes and evaluative classroom observations in the United States had led to a "decline of teacher autonomy". Webb (2002: 48) also uses the term in this sense, when he refers to the ways in which "teachers exercise their autonomy in the face of accountability systems that aim to reduce or eliminate their independent decision-making". Webb aligns the concept of teacher autonomy with Lortie's (1975) notion of "teacher power" and also with Maxcy's (1991: 160) view that "educational professionalism" means "power being placed in the hands of educators such that they may possess leadership in the policy and decision-making affecting learning in schools". Similar views are expressed by Powell \& McGowan (1996), who identify teacher autonomy with teachers' control over their working environments and, in the context of teacher education programmes, teachers' control over their own professional growth, by Clement \& Vandenberghe (2000: 81), who describe teacher autonomy as a "workplace condition", and by Pearson \& Moomaw (2005: 41) who define 
it as "the perception that teachers have regarding whether they control themselves and their work environment".

A somewhat different conception of teacher autonomy has, however, occasionally been articulated in the teacher education literature. Ullrich (1992), for example, identifies a strong sense of personal autonomy as a factor in teachers' ability to implement educational alternatives, while Burk \& Fry (1997) discuss "autonomous teaching beliefs" mainly in terms of teachers' attitudes towards the development of their students' autonomy (see also, DeVries \& Kohlberg 1987: 380). Although it is not especially characteristic of the broader literature on teacher education, this view has received stronger support in the foreign language education literature, where professional freedom has been seen as one, but by no means the most important, element in a conception of teacher autonomy that has largely evolved out of efforts to understand the most appropriate roles for teachers in projects aimed at the development of learner autonomy. In foreign language education, teacher autonomy has largely been viewed as a professional attribute to be developed through teacher education processes and, more recently, through processes of self-directed professional development. It has also been closely linked to a commitment on the part of teachers to the principle of learner autonomy.

This collection of papers on autonomy in foreign language education in Brazil offers an apt opportunity to reflect on the nature of teacher autonomy and its relationship to learner autonomy, because it brings together empirical studies in which the research participants include both foreign language students who are studying languages with the prospect of becoming teachers and practising teachers, who doubtless still consider themselves to be, in some sense, foreign language students. Viewing the collection as one that deals with autonomy at various levels of the learning and teaching process for prospective and practising teachers, therefore, we have a unique opportunity to consider the relationship between learner autonomy and teacher autonomy as one of transition. We begin this paper by placing the idea of teacher autonomy within the development of research and practice on autonomy in foreign language education. We then discuss three major phases in the evolution of research on teacher autonomy, concerned with teacher roles, teacher professionalism and professional freedom. Lastly we return to the relationship between learner autonomy and teacher autonomy as one of transition and attempt to establish a 
theoretical basis for this idea in the notion of personal autonomy as an attribute that is acquired in and across particular domains of an individual's life.

\section{Learner and teacher autonomy in foreign language education}

The origins and development of the idea of autonomy within the field of foreign language education have been described in detail elsewhere (Benson 2001; Gremmo \& Riley 1995). In brief, the concept of autonomy entered the field in the mid-1970s in the context of innovative adult foreign language learning projects (Harding-Esch 1977; Holec 1981). Some of these projects were based in 'self-access' language resource centres where learners were expected to self-direct their learning, while others focused on 'learner training' for self-directed learning. From the late 1980s onwards, however, attention shifted to younger learners and more conventional classrooms, leading to the emergence of a body of literature emphasizing the need to foster the socio-psychological attributes associated with learner autonomy in all foreign language education contexts (Dam 1995; Little 1991). Although this literature forms a relatively small part of the foreign language literature as a whole, it has connected in recent years with the increasingly accepted view that high degrees of foreign language proficiency cannot be achieved through classroom instruction alone. Interest in the idea of learner autonomy has thus increased exponentially over the past 15 years or so to the point where it is now more or less universally acknowledged that successful foreign language acquisition depends upon students achieving and exercising some degree of autonomy in respect to their learning.

In early work in the field of foreign language education, learner autonomy referred both to situations in which learning proceeds independently of teachers or specially prepared teaching materials (Dickinson 1987) and to learners' capacity to take charge of their own learning (Holec 1981). There has been a tendency in more recent work, however, to reserve the term 'learner autonomy' for the capacity to take charge of one's learning, while the terms 'self-directed' or 'independent' learning tend to be used for situations in which this capacity is put to use. 
This tendency is connected, in part, to the rise of classroom-based approaches to learner autonomy in the field. It is widely accepted that most individuals lack the capacity to direct their own foreign language learning, at least in the early stages. It is in this context that the attributes of teachers involved in autonomous learning projects become important. Teachers may be more or less in favour of learner autonomy and more or less skilled in helping their students develop learner autonomy. This is also likely to be related to their own experiences of language learning and teacher education and development.

In the following sections, we discuss three major phases in the evolution of the idea of teacher autonomy in the field of foreign language education. The first phase was focused on discussion of teacher roles prior to the emergence of the concept of teacher autonomy, the second focused on teacher autonomy as an aspect of teachers' professional competence, and the third involves recent discussions of the role of professional freedom in the development of professional competence.

\section{The role of teachers in autonomous learning projects}

Teacher roles were addressed from an early stage in the literature on autonomy in language learning, partly in response to concerns that the idea of autonomy implied a radical restructuring of foreign language education that would ultimately do away with the need for teachers altogether. In a paper entitled "Does the teacher have a role in autonomous learning?" Voller (1997) referred to several papers that had listed attributes and abilities of teachers who were skilled in managing autonomous language learning projects (Dickinson 1987; Holec 1985; Little 1989; Sturtridge 1992). The volume in which Voller's paper appeared also contained several new contributions dealing with teacher roles (Breen \& Mann 1997; O’Dell 1997; Riley 1997; Sheerin 1997; Sturtridge 1997). Discussing the rise of self-access centres, where the teacher's role was perhaps most at risk, Sheerin (1997:.63) pointed to the "paradox of independent learning that almost all learners need to be prepared and supported on the path towards greater autonomy by teachers". Sheerin described the teacher's role in the self-access centre as "a difficult one requiring great skill and sensitivity" (p. 64), involving attention to the twin dangers of providing too much and too little guidance. Sturtridge (1997: 71) argued for teacher development 
programmes to help teachers working in self-access centres "become aware of their new role as facilitators" and pointed to a second paradox: "teachers need to be trained to stop teaching students". Sturtridge also noted that discussions of teacher roles in self-access learning had moved historically from a focus on guidance in the selection and use of learning materials to more complex issues of learner development and individual tutoring, while O'Dell (1997) observed a parallel movement in the concerns of teachers as they became more experienced in self-access centre work.

Other contributions addressed teacher roles in autonomous learning projects in a wider context than the self-access centre. Riley (1997:115), for example, commented that a number of terms had been used to describe "a person working with learners but whose role, behaviour and objectives differ from those of the traditional teacher". These included 'counsellor', 'helper', 'facilitator', 'knower', 'mentor', 'adviser' and 'consultant'. Lack of consensus on the most appropriate term, he argued, reflected basic uncertainties about the roles of teachers in such situations. Attempting to clarify these terminological and conceptual uncertainties, Voller (1997) discussed teacher roles in autonomous learning in terms of Barnes's (1976) contrast between "transmission" and "interpretation" teaching. Discussing four roles compatible with interpretation framework - facilitator, counsellor, resource and negotiator - Voller concluded that "the teacher's role in autonomous learning can be characterized essentially as one of negotiation, both with learners and external authorities" (p.109). Breen \& Mann (1997) also identified three attributes of teachers who engage in a pedagogy for autonomy (self-awareness, belief and trust in learners, and the desire to foster learner autonomy) and six corresponding forms of classroom action (being a resource, decision sharing, facilitating collaborative action, managing risks, being a patient opportunist and getting support). They also suggested that these six ways of acting "seem to entail that, as a teacher, I need to recognize and assert my own autonomy” (p.148). Although Breen \& Mann did not expand on this comment, it has been viewed as crucial link between work on teacher roles in the development of learner autonomy and more recent work on the concept of teacher autonomy.

Aside from its introduction of themes that would appear later in the literature on teacher autonomy - notably concerns with teacher attributes (Breen \& Mann 1997) and the role of teachers as mediators between students and broader educational environments (Voller 1997), the work discussed 
in this section is worthy of consideration for two major reasons. First it explains why teacher autonomy is so strongly linked to learner autonomy in the foreign language education literature: the idea of teacher autonomy was introduced into in this literature by researchers who were primarily interested in learner autonomy. Second, it helps us to see how this idea evolved out of certain practical problems posed by the theory of learner autonomy. In what sense was the presence of teachers required in situations where the students were expected to direct their own learning? How exactly were teachers expected to spend their time and deploy their skills in such situations? And how would teachers trained in more traditional modes of teaching adjust to these new expectations? By the mid-1990s, however, the focus in answers to these questions had begun to shift. Where researchers had previously been concerned exclusively with teacher roles in nonconventional teaching and learning settings, they were now far more concerned with the underlying attributes that would allow teachers to engage in pedagogies for autonomy in the classroom.

\section{Teacher autonomy as a professional attribute}

The concept of teacher autonomy was explicitly introduced into the foreign language education literature in the mid-1990s by Little (1995). Little's paper was preceded, however, by several contributions extending work on teacher roles in autonomous learning projects to classroom settings. Crabbe (1993: p.208), for example, observed that in such situations the goal of autonomy "needs to pervade the whole curricular system". Based on microanalysis of teacher discourse in the classroom, he also argued that the crucial factor in the development of learner autonomy was whether or not "the minute-by-minute classroom practice" encouraged student decision-making. In an especially important contribution to the literature on classroom autonomy, Dam (1995) provided a detailed account of her own role in classrooms where much of the responsibility for decision-making was assigned to students. The main contribution of Little's (1995) paper lay in its application of insights from practical work in classrooms to the theoretical construct of teacher autonomy.

Little's (1995:175) basic premise was that genuinely successful learners have always been autonomous in the sense that they accept responsibility for their learning and possess the "capacity to reflect on the content and 
process of learning with a view to bringing them as far as possible under conscious control". In this sense, he argued, there is nothing new or mysterious about learner autonomy, and "our enterprise is not to promote new kinds of learning, but by pursuing learner autonomy as an explicit goal, to help more learners to succeed”. Like Crabbe (1993), Little argued that the decisive factor in the development of learner autonomy was "the nature of the pedagogical dialogue". In order to conduct such a dialogue effectively, teachers would need to engage in a "probably protracted process of negotiation by which learners can be brought to accept responsibility for their learning" (p.178). They would also need to determine the extent to which it was possible for learners to set their own objectives, select learning materials and contribute to the assessment of their progress, taking account of factors including the institutional framework and the age, educational background and target language competence of the learners (p.179). In order for teachers to do all of these things, the principal requirement was that they should be autonomous in relation to their own practice.

Little was also among the first to discuss teacher education issues within the literature on learner autonomy. According to Little (1995:179),

Genuinely successful teachers have always been autonomous in the sense of having a strong sense of personal responsibility for their teaching, exercising via continuous reflection and analysis the highest degree of affective and cognitive control of the teaching process, and exploring the freedom that this confers.

From this perspective, teacher autonomy is analogous to learner autonomy, differing from it primarily in respect to the object of responsibility and control. Whereas learner autonomy involves responsibility for learning and control over the learning process, teacher autonomy involves responsibility for teaching and control over the teaching process. For this reason, teacher autonomy can also be developed through educational interventions parallel to those leading to the development of learner autonomy. In this sense, teacher education programmes should not simply teach student teachers about the idea of learner autonomy, they should also be oriented towards teacher autonomy as a goal. Arguing that "language teachers are more likely to succeed in promoting learner autonomy if their own education has encouraged them to be autonomous", Little proposed that "teacher education should be subject to the same 
processes of negotiation as are required for the promotion of learner autonomy in the language classroom" (p.180).

While Little's (1995) suggestions for teacher education appeared to have most relevance to pre-service contexts, and rested strongly upon the idea of the teacher as a learner of the craft of teaching, later contributions focused more on in-service contexts and developmental aspects of teacher autonomy. Thavenius (1999:160), for example, defined the autonomous teacher as one "who reflects on her teacher role and who can change it, who can help her learners become autonomous, and who is independent enough to let her learners become independent". Viewing awareness as a crucial dimension of teacher autonomy, she argued that the process of becoming more aware of one's role in the development of learner autonomy required "not only recurrent in-service training and classroom practice, but also a radical change of attitudes and a good insight into introspection" (p.161). Using the term "teacher-learner autonomy", Smith (2000; 2003) emphasised the sense in which teachers are also learners, not only of the craft of teaching but also, in the context of foreign language education, either of the languages they teach or of their students' first languages. From this perspective, ongoing experiences of self-direction in teacherlearning are conducive to teachers' efforts to foster learner autonomy. McGrath (2000) similarly outlines a conception of teacher autonomy as "self-directed professional development" and notes the convergence of this conception with a number of ideas in the broader teacher education literature, such as teacher development, teacher research, reflective practice and action research.

The common thread in the contributions to the literature discussed in this section is the idea that teacher autonomy can be conceptualised as a professional attribute connected, on one hand, to a capacity to control the processes involved in teaching process and, on the other, to a capacity to control one's own development as a teacher. In the first sense, teacher autonomy is a parallel concept to learner autonomy; while autonomous learners control learning, autonomous teachers control teaching. In the second sense, it involves the teacher's own autonomy as a learner; autonomous teachers control the process of learning how to teach, which may include ongoing learning of their subject matter. These conceptions of teacher autonomy, with their emphasis on capacities to control teaching and learning, is somewhat removed from the conception of teacher 
autonomy as professional freedom prevalent in the wider teacher education literature and the absence of this dimension of professional freedom has been identified as a weakness by some foreign language education researchers.

\section{Teacher autonomy as professional freedom}

In foreign language education contexts, the strongest arguments for the incorporation of professional freedom into conceptions of teacher autonomy have been made by Benson (2000) and Mackenzie (2002). Criticising the assumption that learner autonomy develops in institutional settings primarily through 'transfer of control' from teachers to learners, Benson (2000) argued that most teachers work under conditions in which the control that they exercise is severely constrained by factors such as educational policy, institutional rules and conventions, and conceptions of language as an educational subject matter that condition what counts as foreign language teaching and learning. For this reason, the teacher's role in the development of learner autonomy must involve a critical approach towards the ways in which these wider constraints on learning are mediated through his or her agency. Teachers' willingness to go against the grain of educational systems and struggle to create spaces within their working environments for students to exercise greater control over their learning is a crucial aspect of teacher autonomy.

Extending this argument, Mackenzie (2002: 225) took direct issue with Little's (1995) perspective on teacher autonomy, arguing that it:

... appears to assume that teachers only have responsibility for the classes we teach and the students we have 'under' us. There is no sense here that teachers can have responsibility for, or influence over the constraints around us. This focus on control from the outer denies our inner psychological and physical need to change the environment around us towards our own ends. These drives are often strong or misdirected, but used consciously with full awareness of the impact that we are having on others, they can help us act to change our teaching and learning contexts.

Through teachers' accounts of their involvement in curriculum development, Mackenzie went on to explore teachers' inner desires to influence the environments in which they work and to participate in institutional change. Suggesting that institutions can also be viewed as 
learners, Mackenzie suggested that, for teachers, "choosing to participate in curriculum development is the first step towards increasing our own autonomy within our own teaching-learning contexts", while for institutions, "choosing to involve the faculty in their own futures and maintaining their input into curricular choices is the first step to becoming a learning organization" (p.230). Focusing more directly on teachers' wellbeing, Lamb (2000) argues that constraints on the practice of teaching can lead to "cynicism and resignation (in both meanings of the word)" (p.127) and that "teachers need to understand the constraints upon their practice but, rather than feeling disempowered, they need to empower themselves by finding the spaces and opportunities for manoeuvre" (p.128). Barfield, et al. (2002: 220), also argue that teacher autonomy "involves understanding and making explicit the different constraints that a teacher may face, so that teachers can work collaboratively towards confronting constraints and transforming them into opportunities for change", a process that is "driven by a need for personal and professional improvement". And for Vieira (2003: 222) a conception of teaching as a "moral and political activity" presupposes that "teachers are both willing and able to exert some control over educational settings by mediating between constraints and ideals".

In these conceptions of teacher autonomy, it seems particularly important that professional freedom should not simply be 'granted' from above; instead, it should be the outcome of processes of professional development. McGrath (2000), for example, has explicitly attempted to reconcile conceptions of teacher autonomy based on the idea of professional freedom with those based on the idea of self-directed professional activity. $\mathrm{He}$ argues that, from an institutional perspective, constraints on the practice of teaching constitute the structure of professional activity and serve as useful reference points for issues such as standardization and accountability, while from the perspective of individual teachers they may appear more as instruments of control. What is crucial, for McGrath, is the way in which teachers respond to these constraints. The non-autonomous option is simply to accept decisions made by others and carry them out in the classroom. The alternative, he argues, is "not to carve an independent swathe through constraints, rejecting out of hand what may have been put in place for good reason, but to exercise independent judgement in order to establish a principled strategy which may involve compromise and negotiation as well as determined autonomous action" (p.102). This view essentially posits 
teacher professionalism as a pre-condition for teacher autonomy, understood as a form of freedom from constraint achieved through self-directed professional development and activity.

It also seems important that these processes of self-directed development and activity are oriented towards the goal of learner autonomy. Barfield, et al. (2002: 220), for example, define teacher autonomy as "a continual process of inquiry into how teaching can best promote autonomous learning for learners". For Vieira (2003) also, teaching becomes a moral and political activity through an orientation towards the goal of learner autonomy. Her teacher education work for teacher autonomy thus involves a crucial focus on reflective practice and action research around issues of learner autonomy. Indeed, for some writers the implication that professional freedom may be divorced from a commitment to the goal of learner autonomy problematizes definitions of teacher autonomy based on the idea of 'teacher control'. Aoki (2002: 111), for example, offers a similar analogy between learner and teacher autonomy to that proposed by Little (1995):

If learner autonomy is the capacity, freedom, and/or responsibility to make choices concerning one's own learning... teacher autonomy, by analogy, can be defined as the capacity, freedom, and/or responsibility to make choices concerning one's own teaching.

Aoki finds this analogy problematic, however, "because it does not imply in itself that teacher autonomy has any relevance to teachers' capacity to support the development of the autonomy of their learners".

\section{Discussion}

At the beginning of this paper, we observed that the teacher education literature has tended to equate teacher autonomy with professional freedom. Beginning from this observation, we can say that the contribution of foreign language education researchers lies in three main areas.

First, there has been consistent emphasis on the link between learner autonomy and teacher autonomy. This link has been represented in several different ways. Teacher autonomy has been viewed as the capacity to help students develop learner autonomy. It has been viewed as a parallel capacity 
to learner autonomy, concerned with control over teaching, as opposed to control over learning. It has also been viewed as a capacity grounded in teachers' own autonomous learning. There is thus no widespread consensus on the nature of the link between learner and teacher autonomy. Continued attention to the connection between teacher autonomy and learner autonomy seems justified, however, if only because the two concepts share 'autonomy' as their basic term. At the minimum, our conceptions of teacher autonomy should be compatible with the goal of learner autonomy. As Vieira (in Barfield, et al., 2002: 221) asks: "What is the point of having a concept of reflective teaching, teacher empowerment or teacher autonomy which can accommodate transmissive, authoritarian, even oppressive purposes?"

Second, there has been consistent emphasis on teacher autonomy as an attribute of teachers. Again this contrasts with the view that teacher autonomy is equivalent to professional freedom alone. This contrast also echoes discussions in the foreign language education literature on learner autonomy. As we noted, earlier, the term learner autonomy is sometimes used to describe situations in which students learn independently of teachers or teaching materials. This use of the term has been criticised, however, because we cannot necessarily assume that students who find themselves in such situations will be capable of self-directing their learning. They may simply fail or abandon the effort altogether. Moreover, our role as teachers prescribes that we should do more than simply liberate students from educational constraints. We must also enable students to self-direct their learning under conditions of freedom. A parallel argument can perhaps be made for teacher autonomy. Can we take it for granted that teachers are necessarily capable of exercising professional discretion in all situations? Can we be sure that teachers will not use this discretion to, for example, undermine educational reforms that point in the direction of greater learner autonomy? If these are reasonable fears, we may justifiably take the view that it is not enough for professional freedom to be granted from above. Teachers also need to be enabled, through processes of teacher education and development, to exercise professional discretion in ways that will benefit their students' autonomy.

The third contribution relates to the way in which some researchers, recognising that opportunities to exercise professional discretion are often severely constrained, have attempted to incorporate the idea of professional 
freedom into the perspective outlined above. We would readily acknowledge that recent trends in educational administration in many parts of the world are indicative of a lack of trust in teacher professionalism. In this context, a strong distinction between enabling and allowing may represent a false dichotomy. Again there are possible parallels with discussions in the foreign language education literature on learner autonomy. It is often argued that the capacity to self-direct learning is not something that can be taught. It must instead be acquired through experiences of self-direction in significant areas of learning. From this perspective, teacher autonomy does imply professional freedom. Yet it also seems important that this freedom should not simply be granted, but achieved through the self-directed activity leading to higher levels of professional competence. In this sense, teacher autonomy implies the ability and willingness to create spaces for professional freedom in one's own working environment.

The relationship between learner autonomy and teacher autonomy remains a difficult relationship to conceptualize, however, and this is perhaps partly because we tend to understand the two constructs as belonging to two different parties in the teaching and learning process. A long-term view of foreign language teacher education, however, suggests that there is a need for inquiry into the kinds of transition from learner to teacher autonomy that might be expected in the development of an individual from language learner to language teacher. From this perspective, learner and teacher autonomy are not attributes of different people, but of the same person at different, and probably overlapping, periods of the individual's learning-teaching career. This invites us, moreover, to inquire into the sense in which learner and teacher autonomy may be made of the same 'stuff. Would it make sense, for example, to think of learner and teacher autonomy as two varieties of a broader construct of personal autonomy? If it does make sense to think in this way, then the kinds of transitions along the continuum from language learner autonomy to language teacher autonomy that we are able to observe in this volume are of considerable interest.

\section{Conclusion}

In order for learner and teacher autonomy to be understood as matters for education, they must first be conceptualised as attributes that are capable 
of development through educational processes. The case for the possibility of fostering learner autonomy through educational processes has been well made elsewhere. Whether teacher autonomy can also be fostered through educational processes, depends partly on our view of teacher autonomy and partly on our view of teacher education. In this paper, we have favoured a conception of teacher autonomy that incorporates elements of professionalism, professional freedom and self-direction within the process of learning how to teach. This conception of teacher autonomy clearly has practical implications for teacher education at a number of levels, including pre-service and in-service programmes, and teachers' own efforts to improve their professional competence collaboratively.

The literature discussed in this paper includes a number of accounts of teacher education initiatives oriented towards the goal of teacher autonomy (Aoki 2002; Lamb 2000; McGrath 2000; O’Dell 1997; Thavenius 1999; Vieira 2003). A convergence with established approaches such as teacher development, teacher research, reflective practice and action research, noted by McGrath (2000), is a major feature of these initiatives. But it is worth noting that most of the teacher autonomy initiatives reported in the literature involve mature in-service teachers. How we may best go about fostering teacher autonomy among pre-service teacher education students, or among foreign language students who are likely to become language teachers, remains an open question. We would want to argue, however, that the answer to this question will, in some sense, involve the notion of teacher autonomy growing out of and incorporating learner autonomy in the transition from learner to teacher, a transition which is perhaps for the autonomous teacher never complete.

Recebido em maio de 2008 Aprovado em dezembro de 2008 Email: pbenson@ied.edu.hk peterjh@hkusua.hku.hk

\section{REFERENCES}

ANDERSON, L.W. 1987. The decline of teacher autonomy: tears or cheers? International Review of Education, 33: 357-373. 
Aoki, N. 2002. Aspects of teacher autonomy: Capacity, freedom, and responsibility. In: P. Benson \& S. Toogood (Eds.). Learner Autonomy 7: Challenges to Research and Practice (pp. 110-124). Dublin: Authentik.

Areglado, R.J. 1996. Learning for Life: Creating Classrooms for Self-directed Learning. Thousand Oaks, CA: Corwin Press.

Barfield, A., Ashwell, T., Carroll, M., Collins, K., Cowie, N., Critchley, M., Head, E., Nix, M., Obermeier, A. \& Robertson, M.C. 2002. Exploring and defining teacher autonomy: A collaborative discussion. In: A.S. Mackenzie \& E. McCafferty (Eds.). Developing Autonomy. Proceedings of the JALT CUE Conference 2001 (pp. 217-222). Tokyo: The Japan Association for Language Teaching College and University Educators Special Interest Group.

BARnes, D. 1976. From Communication to Curriculum. Harmondsworth: Penguin.

Benson, P. 2000. Autonomy as a learners' and teachers' right. In: B. Sinclair, I. McGrath \& T. Lamb (Eds.). Learner Autonomy, Teacher Autonomy: Future Directions (pp. 111-117). London: Longman.

Benson, P. 2001. Teaching and Researching Autonomy in Language Learning. London: Longman.

Benson, P. 2007. Autonomy in language teaching and learning. State of the art article. Language Teaching, 40: 21-40.

Boud, D. (ed.) 1988. Developing Student Autonomy in Learning. London: Kogan Page.

Breen, M.P., \& Mann, S. 1997. Shooting arrows at the sun: Perspectives on a pedagogy for autonomy. In: P. Benson \& P. Voller (Eds.). Autonomy and Independence in Language Learning (pp. 132-149). London: Longman.

Brockett, R.G. \& Hiemstra, R. 1991. Self-direction in Adult Learning: Perspectives on Theory, Research, and Practice. London: Routledge.

Burk, D.I. \& FrY, P.G. 1997. Autonomy for democracy in a primary classroom: A first year teacher's struggle. Teaching and Teacher Education, 13(6): 645-658.

Candy, P.C. 1991. Self-direction for Lifelong Learning. San Francisco: JosseyBass.

Clement, M. \& Vandenberghe, R. 2000. Teachers' professional development: a solitary or collegial (ad)venture? Teaching and Teacher Education 16(1): 81-101.

Crabbe, D. 1993. Fostering autonomy from within the classroom: The teacher's responsibility. System, 21(4): 443-452. 
DAM, L. 1995. Learner Autonomy 3: From Theory to Classroom Practice. Dublin: Authentik.

DeVries, R. \& Kohlberg, L. 1987. Programs of Early Education: The Constructivist View. White Plains: NY: Longman.

Dickinson, L. 1987. Self-instruction in Language Learning. Cambridge: Cambridge University Press.

Gremmo, M-J. \& Riley, P. 1995. Autonomy, self-direction and self-access in language teaching and learning: the history of an idea. System, 23(2): 151-164.

Hammond, M. \& Collins, R. 1991. Self-directed Learning: Critical Practice. London: Kogan Page.

Harding-Esch, E.M. (ed.). 1977. Self-Directed Learning and Autonomy. Report of a Seminar held at Cambridge, 13-15 December 1976. University of Cambridge, Department of Linguistics and CRAPEL. (Mimeo).

Holec, H. 1981. Autonomy in Foreign Language Learning. Oxford: Pergamon. (First published 1979, Strasbourg: Council of Europe).

Holec, H. 1985. On autonomy: some elementary concepts. In: P. Riley (ed.) Discourse and Learning (pp. 173-190). London: Longman.

LAMB, T.E. 2000. Finding a voice: Learner autonomy and teacher education in an urban context. In: B. Sinclair, I. McGrath \& T. Lamb (Eds.). Learner Autonomy, Teacher Autonomy: Future Directions (pp. 118-127). Harlow, England: Pearson Education.

LitTLE, D. 1989. Self-Access Systems for Language Learning. (With contributions from E. Esch, M.-J. Gremmo, D. Little, H. Moulden, P. Riley \& D. Singleton). Dublin: Authentik / CILT.

LitTle, D. 1991. Learner Autonomy. 1: Definitions, Issues and Problems. Dublin: Authentik.

LitTLE, D. 1995. Learning as dialogue: The dependence of learner autonomy on teacher autonomy. System, 23(2): 175-182.

LoRTIE, D. 1975. Schoolteacher: A Sociological Study. Chicago: University of Chicago Press.

McGrath, I. 2000. Teacher autonomy. In: B. Sinclair, I. McGrath \& T. Lamb (Eds.). Learner Autonomy, Teacher Autonomy: Future Directions (pp. 100-110). Harlow, England: Pearson Education.

Mackenzie, A. 2002. Changing contexts: Connecting teacher autonomy and institutional development. In: A.S. Mackenzie \& E. McCafferty (Eds.). Developing Autonomy (pp.223-232). Proceedings of the JALT CUE Conference 2001. Tokyo: The Japan Association for Language 
Teaching College and University Educators Special Interest Group (JALT CUE-SIG).

MaxCy, S.J. 1991. Educational Leadership: A Critical Pragmatic Perspective. New York: Bergin \& Garvey.

O’Dell, F. 1997. Confidence building for classroom teachers working with self-access resources. In: P. Benson \& P. Voller (Eds.). Autonomy and Independence in Language Learning (pp. 150-163). London: Longman.

Pearson, L.C. \& Moomaw, W. 2005. The relationship between teacher autonomy and stress, work satisfaction, empowerment and professionalism. Education Research Quarterly, 29(1): 37-53.

Powell, J.H. \& McGowan, T.M. 1996. In search of autonomy: Teachers' aspirations and expectations from a school-university collaborative. Teaching and Teacher Education, 12(3): 249-260.

RiLeY, P. 1997. The guru and the conjurer: aspects of counselling for selfaccess. In: P. Benson \& P. Voller (Eds.) Autonomy and Independence in Language Learning (pp. 114-131). London: Longman.

SHEERIN, S. 1997. 'An exploration of the relationship between self-access and independent learning'. In: P. Benson \& P. Voller (Eds.) Autonomy and Independence in Language Learning (pp. 54-65). London: Longman.

Schunk, D.H. \& Zimmerman, B.J. (Eds.). 1994. Self-regulation of Learning and Performance: Issues and Educational Applications. Hillsdale, NJ: Lawrence Erlbaum.

Schunk, D. H. \& Zimmerman, B.J. (Eds.).1998. Self-regulated Learning: from Teaching to Self-regulated Practice. New York: Guildford Press.

SMITH, R.C. 2000. Starting with ourselves: Teacher-learner autonomy in language learning. In: B. Sinclair, I. McGrath \& T. Lamb (Eds.) Learner Autonomy, Teacher Autonomy: Future Directions (pp. 89-99). Harlow, England: Pearson Education.

Sturtridge, G. 1992. Self-access: Preparation and Training. Manchester: British Council.

SturtRIDGe, G. 1997. Teaching and language learning in self-access centres: changing roles? In: P. Benson \& P. Voller (Eds.) Autonomy and Independence in Language Learning (pp. 66-78). London: Longman.

Thavenius, C. 1999. Teacher autonomy for learner autonomy. In: S. Cotterall \& D. Crabbe (Eds.). Learner Autonomy in Language Learning: Defining the Field and Effecting Change (pp. 159-163). Frankfurt am Main: Peter Lang. 
UlLRICH, W.J. 1992. Preservice teachers reflect on the authority issue: A case study of a student teaching seminar. Teaching and Teacher Education, 8(4): 361-380.

VIEIRA, F. 2003. Addressing constraints on autonomy in school contexts: Lessons from working with teachers. In: D. Palfreyman \& R.C. Smith (Eds.). Learner Autonomy across Cultures: Language Education Perspectives (pp. 220-239). Basingstoke: Palgrave Macmillan.

Voller, P. 1997. Does the teacher have a role in autonomous learning? In: P. Benson \& P. Voller (Eds.). Autonomy and Independence in Language Learning (pp. 98-113). London: Longman.

WeBB, P.T. 2002. Teacher power: the exercise of professional autonomy in an era of strict accountability. Teacher Development, 6:1: 47-62.

Zimmerman, B.J. \& SchunK, D.H. (Eds.) 1989. Self-regulated Learning and Academic Achievement: Theory, Research and Practice. New York: Springer-Verlag. 